\title{
Islamic Education Through Islamic Quotes on Instagram: A Study on the Behavioral Changes of Millennial Muslim
}

\author{
Sinta Ari Susanti*, Rosiqoh Nur'aini \\ English Education Department, Culture and Language Faculty, IAIN Surakarta \\ Jalan Pandawa, Pucangan, Kartasura, Sukoharjo 57169, Indonesia. Tel. 0271-781516, Faksimili 0271-782774. \\ Email*: sintaarisusan@gmail.com
}

\begin{abstract}
Islamic quotes as apicture that contains text about Islam has been made by many Instagram users on the last decade. The text usually is about the knowledge of Islam in the form of an advice or information. It is undeniable that Instagram users are dominated by millennials, one of them is millennial muslims. Islamic quotes could be a media for millennial muslim in order to learn about Islam. This study is conducted to analyzethe behavioral changes of millennial muslim after reading Islamic quotes on Instagram. The problems analyzed in this study are the behavioral changes showed by millennial muslim on daily life and the reasons that cause millennial muslim changing behavior. The writer usedGagne and Berliner Theory (Behavioristic Theory) to analyze the behavioral changes. Observation and questioner were used in collecting the data. The data was analyzed using a descriptive qualitative method.The results showed that there were behavioral changes of millennial muslim after reading Islamic quotes on Instagram. Millennial muslim's knowledge about Islam was being deeper due to the intensity of reading the Islamic quotes, so their behaviorslowly changes close to the sharia. Behavioral changeswere a result of the interaction between stimulus, in the form of Islamic quotes, and responses, in the form of behavioral changes. Based on the result, it was concluded that Islamic quotes on Instagram could be used as a media in providing Islamic education for millennial Muslims.
\end{abstract}

Keywords: Behavioral Changes, Islamic Education, Islamic Quotes, Millennial Muslim

\section{INTRODUCTION}

The era of 4.0 industrial revolution has brought advances in information and communication technology that makes it easy for people to access any information, anywhere and anytime. Ayun (2015) agrees with this statement which says that the internet can penetrate the limits of the dimensions of human life, penetrate the time and space of its users. Not surprisingly, at this time a new digital-based space was created that formed a cultural space. This new space is on various social media such as Facebook, Twitter, WhatsApp, Line, Instagram, and so on.

Based on research, the number of social media users in Indonesia is 150 million users with a percentage of $56 \%$ of the total population of Indonesia (Websindo, 2019). There are $80 \%$ of active users on Instagram from total social media users (Global Web Index, 2019). Instagram has become a media that has many users, dominated by users aged 18-34 years (Websindo, 2019). This shows that the majority of Instagram active users are millennial.

Millennials are interested to Instagram accounts for various reasons. According to the uses and gratifications' theory, the reason is to satisfy his needs in obtaining information (Bryden, 2017). Pratiwi (2016) by using the theory of reasoned action also agrees with Bryden, that the factors that influence it are the existence of satisfaction and trust and the attitude of the users themselves. This satisfaction arises because of the variety of features on Instagram that make millennial feel pleasure in themselves.

There are many features on Instagram that interest millennials such as creating a personal profile, communicating, interacting socially with fellow friends on Instagram by uploading, liking, and commenting on content such as photos, videos, and words that are shared in feeds without there are limits (Akbar M. et al, 2019; Pratama A. et al, 2019). Not infrequently today we find many quotes on Instagram. There are 88.4 million contents on Instagram that use hashtag "quotes" (\#quotes), 63.1 million hashtag "quote" (\#quote), and many other hashtags about other quotes (Instagram, 2019). Instagram accounts also appear that upload content about quotes, such as @quotes (2.4 million followers), @thegoodquote (18.5 million followers), @ quranquotesdaily (381 thousand followers) @quotesofalquran (111 thousand followers), @islamicquotes with 133 thousand followers (Instagram, 2019).

Quotes is a message about something in the form of pictures and text. There are many types of quotes, such as loves quotes, eco quotes, education quotes, motivation quotes, Islamic quotes and so on. Quotes that are in the spotlight of millennial especially Muslim millennial are Islamic quotes. Islamic quotes are quotes that contain the teachings of Islam in them such as the teachings of fiqh, aqeedah, morals, and so on that originating from the Quran and Hadith (Aviaty, 2017). Islamic Quotes as an image containing text about Islam has been widely made 
by Instagram users in the last decade. The text usually contains knowledge about Islam in the form of advice and information.

Islamic Quotes can be a medium for millennial Muslims in learning Islamic studies. It is undeniable that Millennial Muslims are currently more active on social media than reading books or participating in outdoor activities. Social media has become a millennial necessity that cannot be separated from everyday life. This is what makes Islamic quotes on Instagram as one of the effective media in spreading Islamic education in the digital era like this. Islamic quotes that contain religious content that will increase religious knowledge, religious feelings and religious actions of readers. In line with Abidin J, et al (2019) that the attitude of diversity is a complex integration between religious knowledge, religious feelings and acts of diversity towards a person. This shows, that religious attitudes related to or closely related to psychiatric symptoms. Psychiatric symptoms in question is the presence of stimuli felt by readers to make changes in the form of action.

Lots of research that considers bad the existence of social media. As Hendro Aryo P's research, Fanny (2017) said that social media can easily influence the identity of its users and is easy to change. In the current era, social media does have a very big influence in determining the identity of its users. However, if millennial becomes a wise user, this influence will not become a major obstacle but will be a great opportunity that facilitates all things, one of which is in education. Millennial can learn about Islam anywhere, anytime without any restrictions.

The novelty of this study is that researchers use a different perspective from previous studies. If previous research says there are adverse effects with changes experienced by social media users, in this study, seeing Islamic quotes will bring a positive impact on Muslim millennials who follow Islamic Islamic accounts or hashtags. The positive impact can be seen from the change in behavior for the better than before carried out by millennial Muslims as an act of implementing Islamic education in this era.

This research was conducted to analyze changes in millennial Muslim behavior after reading Islamic quotes on Instagram. The urgency of this research lies in the effectiveness of Islamic quotes on Instagram as another alternative in channeling Islamic education to millennials in the era of the industrial revolution 4.0 seen from the fund changes in behavior. The problem analyzed in this study is the change in behavior exhibited by millennial Muslims in daily life and the reasons underlying the change in behavior. In analyzing these problems, researchers used behavioristic theory.

\section{MATERIALS AND METHODS}

This paper uses a qualitative approach. Rahmat (2009) explains that qualitative research is one of the research procedures that produces descriptive data in the form of speech or writing and the behavior of the people observed. The method used by the writer is descriptive qualitative. In a qualitative approach, the research instrument is the researchers themself. The subject of this study is millennial Muslims while the object of research is behavior change.

The main step in research is data collection (Sugiyono, 2018). Researchers use questionnaires as a tool to collect data. The questionnaire contains questions about changes in behavior that lead to religious behavior adjusted to Bloom's taxonomy of individual behavior (knowledge, attitudes, and skills). Questions in the questionnaire are open and closed. The sampling technique uses purposive sampling technique. According to Ibrahim (2015), research with a purposive sampling technique, researchers determine indicators for selecting informants with specific goals. In this study, researchers determined several indicators to select informants including the following: being a millennial Muslim, having an Instagram account, having read an Islamic quote.

The researcher analyzed the data using the theory of behavior change from Gage and Berliner. In this case, Islamic Quote is a stimulus while behavior change is a response. Changes in behavior have indicators: seem real and can be measured. The results of this study will be explained in the form of a description of changes in millennial Muslim behavior after reading the Islamic quote and the reasons for the change in behavior.

\section{RESULT AND DISCUSSION}

The term taxonomy comes from greek "Tassein" which means classify, and "nomos" which means a rule. So, taxonomy is an activity to classify a rule. Starting with simple invention about $3 \mathrm{H}$ by Johansen from Italy, the first $\mathrm{H}$ is for head (cognitive), the second is for heart (affective), and the last is for hand (psychomotor). Those three elements are a cycle that connected each other in their own function (Tulasi, 2010: 360-361). In the other hand, this taxonomy known as taxonomy Bloom. According to Bloom, definition about taxonomy is very interesting. Bloom's taxonomy (cognitive, affective, and psychomotor) becomes an important reference in learning process especially the connection with education process and result. All of the education process is directed to make a behavioral changing for student completely, including all of the domains (cognitive, affective, psychomotor).

The theory to analyze the behavioral changes of millennial muslim is behavioral changes theory from 
Gagne and Berliner. According to Gagne and Berliner, learning is a behavioral changes process for every organism through every experience. Learning outcome is a changing that happen to the individual who learn. Learning outcome is not only changing in form of knowledge but also in form of ability for communicating, and building an attitude. Learning outcome is a result that achieved by student after learning with certain time that could be measured using evaluation test (Melvin, 2017: 3). The learning outcome in this research is classified according to Bloom: Cognitive, Affective, and Psychomotor.

\section{Cognitive}

The cognitive domain involves knowledge and the development of intellectual skills (Bloom, 1956). This includes the recall or recognition of specific facts, procedural patterns, and concepts that serve in the development of intellectual abilities and skills. There are three questions in the questioner that developed according to cognitive field. The result is from 50 respondents, 42 people said that their knowledge about Islam is increased after reading Islamic quotes. The perception that improved is about Fiqih, Ibadah Sunnah, Muamalah, Akhlak, Tafsir, and Adab. In addition, 35 people clarify that Islamic quotes is effective in order to increase their knowledge about Islam. Several reasons for judging that it is effective are: Islamic quotes has a content that are easy to understand, it could be an alternative for studying Islam if milenial muslim is lazy to go to Islamic recitation, milenial muslim likes to read a short paragraph on the quote rather than read a book. Here is the chart that show if the knowledge of the respondent is increased:

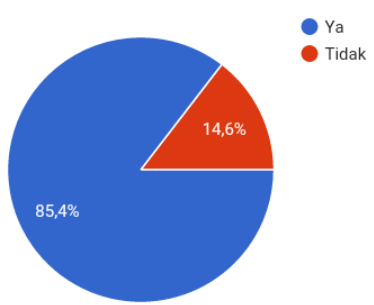

Figure 1. Knowledge of respondents is increased.

\begin{abstract}
Affective
The affective domain involves the feelings, emotions, and attitudes. This domain includes the manner in which people deal with things emotionally, such as feelings, values, appreciation, enthusiasm, motivations, and attitudes. There are four questions that developed according to affective field. The result is from 50 respondents, 40 people said that there is attitude changing after reading Islamic quotes. Their attitude is moved closely to the Islamic attitude such as: patient, discipline, optimistic, wise, respectful, thankful. Moreover, 23 people clarify that Islamic quotes is effective in order to change their attitude. Several reasons for judging that it is effective are: Islamic quotes
\end{abstract}

is more touching than what ustadz said, The content is simple and easy to remember so that it affect people to obey it. Here is the chart that show if the attitude of the respondent is changed:

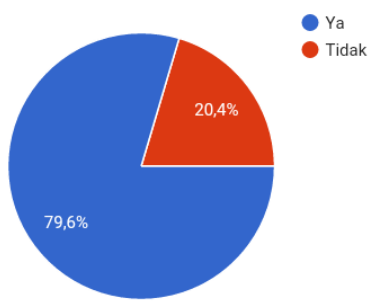

Figure 2. Attitude of respondents is affected

\section{Psychomotor}

The psychomotor domain includes physical movement, coordination, and use of the motor-skill areas (Simpson, 1972). Development of these skills requires practice and is measured in terms of speed, precision, distance, procedures, or techniques in execution. There are four questions that developed according to psychomotor field. The result is from 50 respondents, 39 people said that Islamic quotes affect their action to do Islamic action. The actions that they done are: praying, studying Qur'an, making a du'a, doing a charity, fasting. Moreover, 32 people clarify that Islamic quotes is effective in order to affect them for doing like what Islam commanded. Several reasons for judging that it is effective are: Islamic quotes is as reminder when they forget for doing daily worship, The explanation on the content of Islamic quotes make people believe for doing like what it is written, high intention in using Instagram make people often reading Islamic quotes so that it affect them to do like what it is written. Here is the chart that show if the action of the respondent is changed:

\section{Figure 3. Action of respondents is changed}

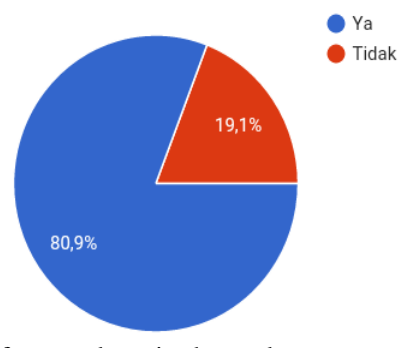

According to the Gagne and Berliner, learning outcome should be measured and obvious. Based on those two indicators (measured and obvious), psychomotor is domain which could fulfill from the three domain according Bloom's taxonomy. Cognitive and affective are could be measured, but they could not seen obviously. Therefore, behavioral changes in this research will be seen from psychomotor domain.

Gagne and Berliner said that learning is an interaction of stimulus and response. In a certain time, individual who learn is given a stimulus. As the outcome, response is in the form of behavioral change. 
Behavioral change according this theory should be fulfill two indicators, measured and obvious.

Stimulus on this research is Islamic quotes whether response is behavioral change in the form of psychomotor. From questioner which given to 50 respondents, 39 people said that Islamic quotes affect their action to do Islamic action. Moreover, 32 people clarify that Islamic quotes is effective in order to affect them for doing an action like what Islam commanded. Several reasons for judging that it is effective are: Islamic quotes is as reminder when they forget for doing daily worship, The explanation on the content of Islamic quotes make people believe for doing like what it is written, high frequency in using Instagram makes people often reading Islamic quotes so that it affect them to do like what it is written.

On learning process, Islamic quotes as stimulus that read in a certain time affect millennial muslim for giving response in the form of their psychomotor which moved to Islamic action. The respondents do like what Islam commanded on their daily life which written as the content of Islamic quotes. Hence, the researcher see there is behavioral change of milennial muslim as the learning outcome which seen from the response in the form of psychomotor that moved to Islamic action after giving stimulus in the form of Islamic quotes.

\section{CONCLUSION}

Based on the results of the study, it can be concluded that there is behavioral changes of millennial muslim as the learning outcome so that Islamic quotes are effective as stimulus on the learning process. This effectiveness is based on the behavioral changes theory according to Gagne and Berliner. The behavioral changes of millennial muslim in this research is in the form of psychomotor which moved to Islamic action. However, from this effectiveness, researchers also provide some notes for millennial Muslims who study Islamic education through Islamic quotes on Instagram. The note is that millennial Muslims need to increase their criticism in reading. Critical in the sense, checking the truth of the hadiths and verses of the Qur'an quoted in these quotes. If this can be achieved, Islamic Quotes can be applied in other learning, such as English education through quotes or other educational objects.

\section{ACKNOWLEDGEMENTS}

We would like to thank our respondents, Millennial Muslims who use Instagram. Thank you also for your beloved campus, IAIN Surakarta, which has become a place to develop our knowledge. Thank you to the many participants who have helped this research and hope we can continue this research going forward as a contribution to Islamic education in Indonesia.

\section{REFERENCES}

Abidin, J.; Fahmi, I. 2019. Media Sosial dalam Mempengaruhi Perilaku Keberagamaan Siswa dan Solusinya Melalui Pendidikan Agama Islam. Jurnal Wahana Karay Ilmiah 3(1): 303-312.

Akbar, M.; Nadjib, M.; Putra, M.R.A. 2019. Kemanfaatan Instagram dalam Pembentukan Citra Diri Remaja Wanita di Makassar. Jurnal Ilmu Komunikasi 2(1): 1-10.

Aviaty, Ikmalia N. 2018. Dakwah Melalui Instagram (Studi Deskriptif Pesan Dakwah Kitabah dalam Quote Instagram @ tausiyahku_Periode Bulan Oktober 2017). UIN Sunan Gunung Djati, Bandung. [Indonesian]

Ayun, P.Q. 2015. Fenomena Remaja Menggunakan Media Sosial dalam Membentuk Identitas. Channel 3(2): 1-16.

Bryden, Lindsey T. 2017. Online Dating Applications and the Uses and Gratifications Theory. [Thesis]. Eastern Washington University, Cheney. [Washington]

Global Web Index. 2019. The Latest Social Media Trends to Know in 2019. www.globalwebindex.com

http://thepeakperformancecenter.com/educationallearning/learning/process/domains-of-learning/affectivedomain/

http://www.nwlink.com/ donclark/hrd/bloom.html

http://www.nwlink.com/ donclark/hrd/bloom/psychomotordomain.html

Ibrahim. (2015). Metode Penelitian Lualitatif. Alfabeta, Bandung.

Instagram. 2019. Quotes Accounts. www.instagram.com

Instagram. 2019. Quotes Tags. www.instagram.com

Melvin, Tria and Surdin. (April, 2017). Hubungan Antara Disiplin Belajar di Sekolah dengan Hasil Belajar Geografi pada Siswa Kelas X SMA Negeri 10 Kendari. Jurnal Penelitian Pendidikan Geografi, Vol. 1, No. 1

Pratama, A.; Puteri, H.A.; Suryanto, T.L.M. 2019. Eksplorasi Teori Gratifikasi untuk Layanan Jejaring Sosial:Studi Kasus Sikap Pengguna terhadap Instagram di Indonesia. Indonesian Journal of Information Systems 2(1): 108-118.

Pratiwi, E.D. 2016. Faktor yang Mempengaruhi Niat Menggunakan Instagram dengan the Theory of Reasoned Action Menggunakan Amos 21. Jurnal Teknik Komputer Amik BSI 2(1): 68-77.

Rahmat, Saeful P. (2009). Penelitian Kualitatif. Equilibrium 5, (9): $1-8$.

Sugiyono. (2018). Metode Penelitian Pendidikan: Pendekatan Kualitatif, Pendekatan Kuantitatif, dan R \& D. Alfabeta, Bandung.

Tulasi, Dominikus. (Oktober, 2010). Merunut Pemahaman Taksonomi Bloom: Suatu Kontemplasi Filosofis. Humaniora, Vol. 1, No. 2

Websindo. 2019. Indonesia Digital 2019: Media Sosial. www.websindo.com 